\title{
Keberadaan Obligasi Syari'ah di Indonesia: Peluang dan Tantangannya
}

\author{
Bachruddin \\ Universitas Islam Indonesia \\ bachruddin@fe.uii.ac.id
}

The role of syari'ah obligation (sukuk) has been prospective, due to the fact that at present people may own certificates of obligation without having to own huge amount of money. Nevertheless, investors must remain to be careful before deciding to invest in this area of business. This is due to the fact that apart from being new area, the issuance of sukuk is also still dominated by the conventional issuers. Therefore, Moslems who want to invest should consider: the agreements between investors and the issuers of sukuk; the background of the issuers of sukuk, whether they are feasible or not. This is important in relation to the return that will be gained by investors, in order for them not to be trapped by "bodong" investment, appearing recently.

Keywords: syari'ah obligation, careful, feasible, investment.

\section{Pendahuluan}

Sekuritas obligasi syari'ah atau lebih Odikenal dengan sebutan sukuk belakangan ini semakin popular. Dengan ciri cukup likuidnya sekuritas investasi syari'ah ini, tidak hanya berkembang di Timur Tengah, namun di Indonesia juga memperlihatkan bahwa sekuritas ini di pasar sekunder sedang mengalami kondisi yang membaik (bullish market). Menurut sementara para pakar, sukuk merupakan salah satu instrumen investasi yang paling mudah diperdagangkan di pasar sekunder.

Model pembiayaan dengan obligasi syari'ah oleh sektor korporat tampak menjadi pilihan. Beberapa perusahaan besar telah menerbitkan obligasi dengan skim syari'ah yang nilainya mencapai ratusan miliar rupiah bahkan sampai triliunan rupiah. Contohnya perusahaan Indofood yang meluncurkan obligasi syari'ah senilai $\mathrm{Rp} 1,5$ triliun, dan mengalami over subscribe.
Kemunculan sekuritas yang berbasis syari'ah ini, kiranya dapat dijadikan langkah awal dalam rangka terciptanya pasar modal syari'ah di Indonesia. Karenanya urgensi keberadaan pasar modal syari'ah sangat dibutuhkan sebagai payung bagi berkembangnya instrumen-instrumen syari'ah di Indonesia.

Dalam skala regional, pasar modal di Malaysia pantas dijadikan sebagia pembanding. Pada tahun 2003 pasar obligasi di Malaysia mencapai 20 miliar dollar AS. Obligasi ini antara lain terdiri atas obligasi yang diterbitkan oleh pemerintah melalui Bank Negara, obligasi khasanah, maupun obligasi yang diterbitkan perusahaan swasta. Dari jumlah kapitalisasi 20 miliar dollar AS itu, sekitar 60\%nya merupakan obligasi syari'ah (MODAL, 2003). 
UNISIA, Vol. XXXI No. 70 Desember 2008

\section{Kajian Pustaka}

\section{Pengertian Obligasi Syari'ah}

Obligasi syari'ah merupakan obligasi diterbitkan dengan ketentuan yang mewajibkan emiten untuk membayar kepada pemegang obligasi syari'ah sejumlah pendapatan bagi hasil dan membayar kembali dana obligasi syari'ah pada tanggal pembayaran kembali dana obligasi syari'ah. Pendapatan bagi hasil dibayarkan setiap periode tertentu yaitu 3 bulan, 6 bulan atau setiap tahun.

Merujuk kepada fatwa Dewan Syari'ah Nasional No. 32/DSN-MUI/IX/2002, pengertian obligasi syari'ah adalah suatu surat berharga jangka panjang berdasarkan prinsip syari'ah yang dikeluarkan emiten kepada pemegang obligasi syari'ah yang mewajibkan emiten untuk membayar pendapatan kepada pemegang obligasi syari'ah berupa bagi hasil/margin/fee, serta membayar kembali dana obligasi pada jatuh tempo.

Menurut AAOIFI obligasi syari'ah atau dikenal dengan sukuk adalah sertifikat yang bernilai sama yang mewakili kepemilikan yang tidak dibagikan atas suatu aset berwujud, nilai manfaat dan jasa-jasa atau kepemilikan atas aset dari proyek tertentu atau kegiatan investasi tertentu. Sementara itu, Mohd Daud Bakar bahwa sukuk atau Islamic Sovereign Bond merupakan surat utang negara di mana penerbit obligasi berutang kepada investor. Investasi obligasi syari'ah tidak hanya berfokus pada obligasi ljarah saja namun lebih luas cakupannya, dapat juga dilakukan dengan akad Istishna'.

Dari definisi di atas dapat dipahami bahwa obligasi syari'ah berbeda dengan obligasi konvensional. Penggunaan nama "obligasi syari'ah" pada awalnya banyak dipertentangkan, karena istilah obligasi berkaitan dengan bunga, sehingga tidak mungkin untuk dikemas ke dalam nilai-nilai Islam. Namun sebagaimana juga pada pengertian bank syari'ah yang berbeda dengan bank konvensional, dimana letak perbedaan yang sangat mendasar adalah antara sistem bunga (konvensional) dengan sistem bagi hasil (syari'ah), demikian juga adanya pergeseran pengertian pada obligasi.

Dalam berinvestasi pada obligasi syari'ah, tidak ada larangan bagi para investor baik dari institusi-institusi syari'ah maupun investor konvensional untuk dapat menikmati dan ikut berpatisipasi dalam obligasi syari'ah.

Bagi emiten, menerbitkan obligasi syari'ah berarti juga memanfaatkan peluangpeluang tertentu. Selain itu struktur obligasi syari'ah yang inovatif, juga memberi peluang untuk memperoleh biaya modal yang kompetitif dan menguntungkan. Namun tidak semua emiten dapat menerbitkan obligasi syari'ah, ada syarat-syarat yang harus dipenuhi dalam penerbitan obligasi dengan skim syari'ah ini, diantaranya:

1. Aktivitas utama yang halal dan tidak bertentangan dengan substansi fatwa No : 20/DSN-MUI/IV/2001.

2. Peringat Investment Grade

3. Termasuk dalam Jakarta Islamic Indeks

4. Memiliki fundamental keuangan yang bagus, dan

5. Perusahaan dinilai baik oleh masyarakat

Mengenai mekanisme pembagian pendapatan bagi hasil dalam obligasi syari'ah adalah bergantung pada besarnya return (pendapatan) bagi hasil dihitung berdasarkan perkalian antara nisbah bagi pemegang obligasi syari'ah dengan pendapatan yang dibagi-bagikan. Pembayarannya diberikan kepada pemegang obligasi syari'ah secara 
Keberadaan Obligasi Syari'ah Di Indonesia...; Bachruddin

proporsional sesuai dengan porsi kepemilikan obligasi syari'ah dibandingkan dengan jumlah dana obligasi syari'ah yang belum dibayar kembali.

\section{Sejarah Obligasi Syari’ah}

Obligasi syari'ah (sukuk) merupakan istilah lama yang telah dikenal dalam sejarah islam. Istilah tersebut telah dikenal sejak abad pertengahan, dimana umat Islam menggunakannya dalam konteks perdagangan internasional. Sukuk merupakan bentuk jamak dari kata sakk. la dipergunakan oleh para pedagang pada masa itu sebagai dokumen yang menunjukkan kewajiban finansial yang timbul dari usaha perdagangan dan aktivitas komersial lainnya. Namun demikian sejumlah penulis Barat yang memiliki concern terhadap sejarah Islam dan bangsa Arab, menyatakan bahwa sakk inilah menjadi akar kata "cheque" dalam bahasa latin, dimana pada saat ini dipergunakan dalam transaksi dunia perbankan syari'ah (Chair, 2007).

Dalam perkembangannya, The Islamic Jurisprudence Council (IJC) kemudian mengeluarkan fatwa yang mendukung perkembangan sukuk. Hal tersebut dapat mendorong Otoritas Moneter Bahrain (Bahrain Monetary Agency) untuk meluncurkan salam sukuk berjangka waktu 91 hari dengan nilai 25 juta dollar AS pada tahun 2001 (Adam dan Thomas, 2004).

Harus diakui, bahwa sukuk merupakan salah satu bentuk terobosan baru dalam dunia keuangan Islam, meskipun istilah tersebut adalah istilah yang memiliki akar sejarah yang panjang. Inilah barangkali salah satu produk yang paling inovatif dalam pengembangan sistem keuangan Islam kontemporer.

\section{Perkembangan Obligasi Syari'ah di Indonesia}

Pada awalnya, penerbitan obligasi syari'ah di Indonesia dipelopori oleh PT Indonesian Satelite Corporation Tbk, (Indosat). Ketika itu indosat hanya menawarkan sekitar 10-20 persen saja dari obligasinya dengan skim syari'ah. Dari sejumlah 1 triliun rupiah, kala itu Indosat melempar sekitar 100 miliar rupiah ke pangsa pasar modal syari'ah. Dalam peluncurannya respon pasar sangat positif bahkan Indosat mengalami kelebihan permintaan (oversubscribe) hingga meningkatkan penawaran mudharabahnya menjadi 175 miliar rupiah.

Dengan melihat penerbitan obligasi syari'ah Indosat, diharapkan pangsa pasar investasi pada instrumen syari'ah akan lebih berkembang. Industri obligasi syari'ah di Indonesia diharapkan bisa berkembang seperti di Malaysia yang telah mencapai hasil di atas Rp 3 milliar. Selain itu, potensi investor dari negara Muslim di seluruh dunia mencapai jumlah di atas US\$7000 miliar, suatu jumlah yang tidak sedikit dan sangat signifikan untuk dijadikan pasar yang perspektif bagi obligasi syari'ah ke depan.

Obligasi syari'ah yang diterbitkan oleh PT. Indosat saat ini merupakan salah satu obligasi syari'ah yang memberikan return rata-rata paling tinggi. Atas prestasinya itu obligasi syari'ah milik PT. Indosat memperoleh rating Triple A Plus. Dengan return setara rate yang pernah mencapai 20 persen dan terendah 16 persen, obligasi syari'ah PT. Indosat yang menggunakan akad bagi hasil ini merupakan obligasi syari'ah pertama yang tercatat di Bursa Efek Surabaya (BES). Atas prestasinya PT. Indosat menerima penghargaan dari BES sebagai The First Syari'ah Bond Listed on Surabaya Stock Axchange (SSX). (Majalah Ekonomi Syari'ah, 2005). 
UNISIA, Vol. XXXI No. 70 Desember 2008

Melihat suksesnya obligasi syari'ah yang diluncurkan oleh PT. Indosat Tbk, beberapa emiten menyusul meluncurkan obligasi syari'ah, diantaranya : PT. Berlian Laju Tanker Tbk dengan nilai emisi Rp 60 miliar, PT. Bank Bukopin dengan nilai emisi Rp 50 miliar, PT. Bank Muamalat Indonesia Tbk (BMI) dengan nilai emisi Rp 200 miliar, PT. Bank Syari'ah Mandiri (BSM) dengan nilai emisi Rp 200 miliar (Iggi H Achsien, 2003), dan PT. Indofood Sukses Makmur Tbk (Indofood) dengan nilai emisi Rp 1,5 triliun (Nugraha, 2003).

Maraknya penerbitan obligasi syari'ah ini selain mempunyai prospek yang menjanjikan juga karena, kemasan yang ada pada obligasi syari'ah telah menarik minat orang untuk berinvestasi serta telah mempunyai legitimasi dari Dewan Syari'ah Nasional (DSN) akan kebolehannya dengan keluarnya fatwa DSN No. 32/DSN-MUI/IX/ 2002. Selain dijamin akan kehalalan dari investasi obligasi dengan skim syari'ah ini, karena ada syarat-syarat (klausul-klausul) yang harus dipenuhi oleh setiap obligasi syari'ah.

Perkembangan yang cukup signifikan dalam investasi obligasi syari'ah tidak hanya di Indonesia saja, tetapi negara lain telah lama berkembang, misalnya Malaysia yang $43 \%$ obligasi yang diterbitkan perusahaanperusahaan sudah memakai pola syari'ah. Di Kuwait telah berhasil menjaring dana sebesar 200 juta dolar AS melalui penerbitan obligasi syari'ah oleh perusahaan Liwuidity Management Centre BSC (LMC). Obligasi syari'ah terbesar di Kuwait ini bernama Lagoan City Islamic Musharaka Sukuk (LCIMS) dengan berskala internasional, bahkan obligasi syari'ah ini mengalami oversubscription hingga 75 juta dolar AS.

Berdasarkan data HSBC Amanah, sejak tahun 2002 hingga tahun 2006 seluruh obligasi syari'ah (sukuk) di dunia diistimasi bernilai 32 miliar dolar AS. Lebih dari 50 persen sukuk tersebut diterbitkan di pasar modal domestik Malaysia dalam mata uang ringgit. Sedangkan penerbitan sukuk dalam mata uang dolar AS di pasar internasional hanya mencapai 41 persen dari seluruh sukuk di dunia (Republika, 2007).

Di Dubai, perusahaan DIFC Investments LLC menerbitkan obligasi syari'ah (sukuk) senilai 1,25 miliar dollar AS. Sukuk terebut memiliki tenar selama lima tahun dan tercatat sebagai sukuk terbesar di wilayah Timur Tengah. Menurut Omar, (DIFC Governor), penjualan sukuk tidak hanya menargetkan Timur Tengah saja, tetapi juga akan menggaet investor luar kawasan, bahkan DIFC menargetkan 67 persen dana investasi terjaring oleh sukuk tersebut berasal dari investor luar kawasan. (Republika, 2007).

\section{Jenis-jenis Investasi Obligasi Syari'ah}

Menurut standard AAOIFI obligasi syari'ah dibagi menjadi 14 macam. Namun secara garis besar obligasi syari'ah yang digunakan di Indonesia berdasarkan fatwa yang dikeluarkan oleh DSN-MUI, diantaranya adalah:

\section{1) Obligasi Ofjarah}

Obligasi ijarah adalah obligasi syari'ah yang berdasarkan akad ijarah dengan memperhatikan substansi fatwa Dewan Syari'ah Nasional MUI tentang pembiayaan ijarah, terutama mengenai rukun dan syarat akad.

Dalam obligasi syari'ah ijarah ini ada ketentuan umum yang menyebutkan pemegang Obligasi Syari'ah ljarah (OSI) dapat bertindak sebagai musta'jir (penyewa) dan dapat pula bertindak sebagai mu'jir 
Keberadaan Obligasi Syari'ah Di Indonesia...; Bachruddin

(pemberi sewa). Emiten dalam kedudukannya sebagai wakil pemegang OSI dapat menyewa atau menyewakan kepada pihak lain dan dapat pula bertindak sebagai penyewa. Sedangkan ketentuan khusus antara lain menyebutkan bahwa objek ijarah harus berupa manfaat yang dibolehkan, jenis usaha yang dilakukan emiten tidak boleh bertentangan dengan syari'ah Islam, dengan memperhatikan fatwa DSN-MUI tentang pedoman Pelaksanaan Investasi untuk Reksadana Syari'ah dan tentang Pasar Modal dan Pedoman Umum Penerapan Prinsip Syari'ah di Bidang Pasar modal.

Emiten dalam kedudukannya sebagai penerbit obligasi dapat mengeluarkan OSI baik untuk aset yang telah ada maupun aset yang akan diadakan untuk disewakan pemegang aset (a'yan) atau manfaat (manafi), dalam menyewakan (ijarah) aset atau manfaat yang menjadi haknya kepada pihak lain, dilakukan melalui emiten sebagai wakil. Emiten yang bertindak sebagai wakil dari pemegang OSI dapat menyewa untuk dirinya sendiri atau menyewakan kepada pihak lain.

Dalam hal emiten bertindak sebagai penyewa untuk dirinya sendiri, maka emiten wajib membayar sewa dalam jumlah dan waktu yang telah disepakati sebagai imbalan ('iwadh ma'lum) sebagaimana jika penyewa dilakukan kepada pihak lain. Mengenai kepemilikan, obligasi syari'ah dengan akad ijarah ini dapat dialihkan kepemilikannya kepada pihak lain, selama disepakati dalam akad. Jika salah satu pihak tidak menunaikan kewajibannya (wanprestasi) atau jika terjadi perselisihan di antara kedua belah pihak, maka penyelesaiannya dilakukan melalui Badan Arbitrasi Syari'ah setelah tidak tercapai kesepakatan melalui musyarawah.
2) Obligasi OMudharabah

Obligasi syari'ah dengan akad mudharabah ini diterbitkan berdasarkan perjanjian atau akad kedua belah pihak, dimana satu pihak bertindak sebagai shahibul al-maal dan pihak lain bertindak sebagai mudharib dalam akad ini kedua belah pihak menyepakati atas keuntungan (margin) untuk dibagi berdasarkan perbandingan yang telah disepakati sebelum akad, misalnya, 60:40. kerugian akan ditanggung sepenuhnya oleh shahibul al-maalselama kerugian tesebut disebabkan karena kondisi pasar dan bukan diakibatkan karena kesalahan di pihak mudharib.

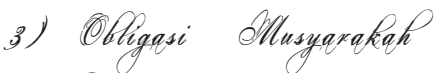

Obligasi dengan kontrak musyarakah ini merupakan bentuk kerjasama antara dua pihak atau lebih dengan menggabungkan modal untuk keperluan suatu proyek tertentu, atau mengembangkan proyek yang telah ada. Dalam kontrak ini keuntungan maupun kerugian akan dibagi dan ditanggung bersama sesuai jumlah persentase modal yang telah disetor oleh para pihak.

$$
\text { 4) OBgasi Cstisna }
$$
berdasarkan bentuk perjanjian jual beli antara dua pihak untuk pembiayaan suatu proyek di mana cara dan jangka waktu penyertaan barang serta harga ditentukan diawal akad berdasarkan kesepakatan para pihak.

\section{Pembahasan}

Kalau kita lihat ke belakang bahwa maraknya pasar obligasi tidak terlepas dari kelemahan industri perbankan. Pascakrisis, perbankan di Indonesia sangat selektif dan cenderung menahan diri untuk melakukan 
ekspansi pinjaman, sementara sektor riil sangat membutuhkan dukungan pendanaan bagi ekspansi usahanya. Akibatnya, perusahaan mulai menerbitkan obligasi untuk memenuhi kebutuhan dananya, dan pasar merespons dengan positif, karena obligasi dianggap sebagai alternatif investasi yang menguntungkan.

Obligasi syari'ah dinilai prospektif, namun untuk mensosialisasikan tidaklah mudah. Hal ini disebabkan masyarakat kita belum terbiasa dengan sistem bagi hasil (profit sharing) ataupun sistem syari'ah lainnya.

Tantangan yang lain ialah menyangkut perdagangan obligasi syari'ah di pasar sekunder untuk tujuan likuiditas. Hampir semua Islamic bonds dibeli untuk investasi jangka panjang, sampai jatuh tempo. Lebih banyaknya investor yang buy and hold memang akan membuat pasar sekundernya kurang likuid. Hal ini terjadi pada Obligasi Syari'ah Mudharabah Indosat (Achsien, 2003).

Maraknya obligasi syari'ah kiranya dapat menjadi tonggak awal bagi pergeseran paradigma dari saving society (masyarakat penabung) yang mengagungkan simpanan sebagai tujuan penempatan dana menuju investing society (masyarakat investor) yang lebih mengarah pada minat investor. Walupun bullish-nya pasar obligasi syari'ah, investor tetap perlu hati-hati sebelum memutuskan untuk berinvestasi di obligasi ini. Banyak kemungkinan dari penerbit obligasi syari'ah yang tidak mengindahkan klausul-klausul dalam akad yang sesuai dengan syari'ah Islam, hal ini dapat terjadi di mana para emiten-emiten (perusahaanperusahaan) mengambil kesempatan dalam penerbitan obligasi syari'ah yang lagi marak di dunia investasi dan instrumen ini paling mudah diperdagangkan di pasar sekunder.
Satu hal lagi yang perlu diperhatikan oleh para investor dalam memilih investasi di obligasi ini adalah mengenai peringkat (rating) sehingga para investor tidak merasa ragu dalam hal pengembalian seluruh hutang dan return yang akan didapatkan dalam berinvestasi pada instrumen ini. Peringkat (rating) sangat perlu dilakukan sebelum obligasi ditawarkan kepada masyarakat pemodal, pemeringkatan dilakukan oleh lembaga pemeringkat (rating agency). Proses pemeringkatan ini sangatlah berguna untuk menilai kinerja perusahaan dari berbagai faktor yang secara langsung maupun tidak langsung berhubungan dengan keuangan perusahaan karen aobligasi merupakan surat hutang sehingga rating sangat diperlukan untuk menilai apakah penerbit nantinya dapat membayar kembali seluruh hutangnya atau tidak, sesuai dengan penilaian rating agency (Sunariyah, 2006).

\section{Penutup}

Ada perbedaan mendasar antara obligasi dengan skim syari'ah dengan obligasi konvesional, dimana dalam obligasi syari'ah pendapatan yang diberikan tidak lagi berdasarkan bunga, tetapi bagi hasil (profit sharing) atau margi/fee. Obligasi syari'ah didefinisikan sebagai surat berharga jangka panjang berdasarkan prinsip syari'ah yang dikeluarkan emiten kepada pemegang obligasi syari'ah yang mewajibkan emiten untuk membayar pendapatan kepada pemegang obligasi syari'ah berupa bagi hasil/margin/fee, serta membayar kembali dana obligasi pada saat jatuh tempo, sedangkan obligasi konvensional adalah surat hutang dari suatu lembaga atau perusahaan yang dijual kepada investor untuk mendapatkan dana segar.

$$
\text { Obligasi dengan skim syari'ah }
$$


Keberadaan Obligasi Syari'ah Di Indonesia...; Bachruddin

merupakan kegiatan berinvestasi jangka panjang dengan keuntungan (margin) yang menarik dan mempunyai prospek yang sangat menjanjikan, terbukti ketika Indosat meluncurkan obligasi dengan skim syari'ah ini dapat dibilang sukses bahkan mengalami kelebihan permintaan (oversubscribe).

Dalam kiprahnya obligasi syari'ah dapat dibilang sangat prospektif dalam dunia bisnis, pasalnya dulu obligasi hanya dapat dimiliki oleh pemodal-pemodal besar karena harus menyediakan uang minimal 1 miliar rupiah untuk setiap sertifikat obligasi, namun sekarang dengan uang yang bisa dibilang tidak begitu besar dapat memiliki sertifikat obligasi dengan skim syari'ah ini.

Walaupun obligasi syari'ah dinilai sangat prospektif dalam investasi, investor tetap perlu hati-hati sebelum memutuskan untuk berinvestasi di obligasi ini, selain tergolong masih baru dalam konteks Indonesia obligasi syari'ah masih didomenasi oleh emiten-emiten konvensional dalam menerbitkan obligasi syari'ah. Yang perlu diperhatikan oleh investor Muslim khususnya adalah mengenai akad yang disepakati antara investor dengan emiten dalam berinvestasi pada obligasi syari'ah (sukuk). Selain itu juga, tentang latar belakang dari perusahaan (emiten) yang menerbitkan obligasi syari'ah, apakah dinilai "layak" menerbitkan sukuk ini atau tidak. Hal ini perlu diperhatikan menyangkut return yang akan didapatkan oleh investor, sehingga tidak terjebak pada investasi "bodong" yang marak belakangan ini.

\section{Daftar Pustaka}

Antonic, Muhammad Syafi'i,2001. Bank Syari'ah dari Teori ke Praktik, Jakarta : Gema Insani Press.

Bodie, Kane, Marcus,2005. Investment, $6^{\text {th }}$ , McGraw-Hill Companies.

Chair, Wasihnl,2007. Prospektif Investasi Pada Obligasi Syari'ah, Kertas Kerja Kosentrasi Keuangan dan Perbankan Syari'ah, UIN, Yogyakarta.

Dewan Syari'ah Nasional-MUI,2002. Himpunan Fatwa Dewan Syari'ah Nasional, Jakarta Bank IndonesiaDewan Syari'ah Nasional.

Dewi, Dinar Kencana, Peluang Individu Beli Obligasi Syari'ah. MODAL No. 13/11November-2003.

Nugraha, K, Giliran Indofood Lirik Obligasi Syari'ah, MODAL No. 9/1-Juli-2003.

Nugroho Ugie, Obligasi Korporasi, antara Ancaman dan Peluang Bagi Perbankan, Kompas, 24 Januari 2004.

Majalah Ekonomi Syari'ah, 2005

Republika, 2007 